уставлен в статье 15 СК РФ. Также в соответствие с СК РФ в ряде особых обстоятельств, брак может быть заключен в день, когда было подано заявление.

Не маловажным моментом будет и то, что ни семейное законодательство, ни уголовно-исполнительное, не устанавливают запрета на вступление в брак с лицами, осужденными к лишению свободы и отбывающими наказание в местах лишения свободы. В данном случае регистрация брака осуществляется в общеустановленном порядке, т.е. согласно Федеральному закону от 15 ноября 1997 г. № 143-Ф3 «Об актах гражданского состояния». Возможно, что ведомственные нормативно-правовые акты содержат нормы, определяющие только техническую сторону процедуры регистрации брака с осужденными, т.к. осужденные лишены права свободного передвижения вне пределов колонии не могут как раз находиться при регистрации брака в органах ЗАГС [4].

Таким образом, можно сделать следующие выводы. Процесс регистрации брака представляет собой правоизменяющий юридический факт, который ориентирован на появление нового юридического статуса, называемого «состоянием супружества», что влечет возникновение таких субъектов семейных правоотношений, как «супруги», которые вступают в отношения, регулируемые нормами не только семейного права, да и гражданского права, жилищного права, права социального обеспечения и др., что закрепляет за данными отношениями гарантированность и защищенность, также правовую определенность. Стоит включить в семейный кодекс определение брака, что позволит разрешить споры по поводу разграничения понятий «сожительство» и «гражданский брак». В абз. 2 и 3 ч. 1 ст. 11 СК РФ закрепить четкий, исчерпывающий список уважительных причин, которые разрешают заключение брака до истечения месяца со дня подачи заявления о заключении брака и особенных обстоятельств, при которых брак может быть заключен в день подачи заявления.

$$
* * *
$$

1. Федеральный закон от 15.11.1997 № 143-Ф3 «Об актах гражданско-го состояния» // Собрание законодательства РФ. - 1997. - № 47. - ст. 5340.

2. Семейный кодекс Российской Федерации от 29.12.1995 N 223-Ф3 (ред. от 02.07.2021) // СПС Консультант Плюс.

3. Феномен рыночного хозяйства: векторы и особенности эволюции: Инновации бизнеса и бизнес инноваций / И. Н. Абанина, А. А. Айт-манбетова, М. Л. Альпидовская [и др.]. - Краснодар: НИИ Южного Федерального округа, 2017. - 632 с.

4. Юкашева С.В. Государственная семейная политика / С.В. Юкашева // Петербургская социология сегодня. 2019. — T. 2. — № 1. — C. 167-168.

\title{
Панова К.В.
}

\section{История развития института брака в дореволюционный и советский период}

Кубанский государственный аграрный университет имени И. Т. Трубилина (Россия, Краснодар)

doi: 10.18411/trnio-01-2022-191

\section{Аннотация}

Институт брака имеет очень древнюю историю, однако аспекты, связанные с его становлением, до сих пор оказывают влияние на современном этапе общественного развития. Данная статья посвящена анализу становления брачно-семейных отношений в имперской России и СССР. В ней исследуются особенности различных нормативноправовых актов, регулировавших семейные отношения эпохи XIX-XX веков. Кроме того, в работе рассматриваются проблемы, возникшие в ходе принятия первых декретов советской власти в области семейных отношений. Представлены выявленные в ходе исследования различия дореволюционных и советский законодательных актов. Также раскрывается эволюция содержания понятия «брак» Особое внимание уделяется анализу условий 
вступления и препятствий к заключению брака на различных этапах становления данного общественного института

Ключевые слова: церковный брак, семейные правоотношения, закон, заключение брака, добровольный союз, развод.

\section{Abstract}

The institution of marriage has a very ancient history, but aspects related to its formation still have an impact on the current stage of social development. This article is devoted to the analysis of the formation of marriage and family relations in imperial Russia and the USSR. It examines the features of various normative legal acts regulating family relations of the XIX-XX centuries. In addition, the paper examines the problems that arose during the adoption of the first decrees of the Soviet government in the field of family relations. The differences between prerevolutionary and Soviet legislative acts revealed in the course of the study are presented. The evolution of the content of the concept of "marriage" is also revealed, special attention is paid to the analysis of the conditions of entry and obstacles to marriage at various stages of the formation of this public institution.

Keywords: church marriage, family legal relations, law, marriage, voluntary union, divorce.

На протяжении всей истории существования государства семья являлась важнейшей ценностью для русского народа, поэтому вопрос о богатой истории процесса ее создания не теряет актуальности и по сей день. Г.Б. Шершеневич одним из первых российских юристов сформулировал понятие брака: «Брак есть союз мужчины и женщины, с целью сожительства, основанный на взаимном соглашении и заключенный в установленный форме». [1]. По мнению цивилиста, главной целью данного института является сожительство как в физическом, так и в нравственном понимании.

Стоит отметить, что в дореволюционной России признавался только брак, который был заключен в церкви (обряд венчания). С 1832 года порядок его оформления регулировался книгой 1 Свода законов гражданских «О правах и обязанностях семейных». Права и обязанности молодоженов, взаимоотношения родителей с детьми, вопросы прекращения брака все еще регламентировались законодательством XVIII века.

Важную роль играли условия создания брачного союза. Во-первых, достижение определенного возраста, который составлял 18 лет для жениха и 16 лет для невесты. При этом церковно-государственное право закрепляло и верхний возрастной предел вступления лиц в брак - 80 лет. Во-вторых, для того, чтобы обвенчаться, дети сначала должны были получить согласие родителей. Для государственных служащих устанавливалось дополнительное условие - дозволение начальства на их брак. Исключение составляли находящиеся на обязательной военной службе нижние чины, которым женитьба запрещалась на законодательном уровне. При отсутствии письменного согласия начальника к служащим применялся строгий выговор с занесением в формулярный список, но при этом брак не считался недействительным. Запрещались браки лиц, между которыми присутствует кровная связь или свойство. Также в XIX веке для христиан устанавливалось ограничение на количество последующих браков, в которые может вступить одно лицо. Так нельзя было вступать в брак в четвертый раз. Кроме того, женатый мужчина или замужняя девушка не могли заключить новый брак без расторжения предыдущего. а лица, которые дали монашеский обет, вообще были не вправе связывать себя брачными узами.

Статьей 85 Свода законов гражданских устанавливался запрет на создание семейного союза христианина с лицом иного вероисповедания. Обряд венчания православного и католика признавался действительным, если его совершал православный священник. Вместе с тем, непосредственно перед обрядом у таких пар обязательно бралась подписка о том, что их дети будут крещены и воспитаны в духе православия.

В конце 1890x - начале 1900x гг. церемония бракосочетания осуществлялась непосредственно в православном храме. Чтобы обвенчаться, будущему мужу и жене сначала 
требовалось получить благословение от местного священнослужителя. В случае если пара изъявляла желание связать себя брачными узами в другом храме, священник местного храма подписывал бумагу о наличии или отсутствии препятствий к заключению брака и выдавал ее им на руки. После обряда молодоженам выдавался документ о совершенном венчании, который признавала не только церковная, но и гражданская власть. Патриархальное нормы закрепляли за мужем статус главы семейства, которому дети и супруга должны были полностью повиноваться. Младшее поколение обязательно должно было выражать почтение к старшим и послушание во всем, в противном случае они могли быть отданы на суд.

С правовой точки зрения имущество между молодыми делилось поровну. Также для взрослых детей предусматривалась обязанность материально содержать престарелых родителей [2]

Церковь рассматривала брак как соединение двух родственных душ раз и навсегда как на земле, так и на небесах. Однако, в силу потребностей мирской жизни церковное право все же предусматривало понятие «прекращение брака». Брачные узы утрачивали свою силу либо в связи со смертью одного из супругов, либо на основании решения общественной власти, если лицо лишалось всех прав состояния. Помимо этого, муж или жена имели право отказаться от совместной жизни, если докажут, что дальнейшая семейная жизнь для них невыносима по вине одного из супругов. При наличии вины мужа его супруга сохраняла право на получение дальнейшего содержания от него.

Обратим внимание, что признание брака недействительным являлось полномочием Синода. Согласно статистическим данным, приведенным в различных исторических документах, доля разводов в Российской империи была практически минимальна - около $5 \%$.

События Октябрьской революции ознаменовались радикальными изменениями в социальной, идеологической и экономической жизни страны. Коренные перемены коснулись и семейного права. Пришедшие к власти большевики 18 декабря 1917 года приняли Декрет ВЦИК и СНК, согласно которому церковная форма брака утратила свою юридическую силу. После принятия данного декрета регистрация процедуры бракосочетания стала находиться исключительно в ведении органов государственной власти. Таким образом, верующие граждане могли обвенчаться, но, чтобы их брак имел правовые последствия, необходимо было предварительно зарегистрировать его в органах ЗАГС. Однако, церковные браки, заключённые до революции, признавались советской властью и не требовали переоформления.

Стоит обратить внимание на то, что с 1917 года процесс создания новой ячейки общества был значительно упрощён по сравнению с дореволюционным периодом: первой ступенью была подача парой заявления в управу в письменной или даже устной форме. Брачующимся также было необходимо приложить расписку об отсутствии препятствий к оформлению брака. При этом сама расписка составлялась с их слов и на практике предварительно не проверялась государственными органами. Перечень условий для заключения браков предельно сократился: теперь от будущих супругов требовалось лишь взаимное согласие и достижение определенного возраста (18 лет для молодых людей и 16 для девушек). Семейный союз считался оформленным после занесения события в книгу записей браков.

Ряд исследователей полагает, что после революции в обществе появилась новая проблема, которая заключалась в том, что нововведения советской власти привели к легкомысленному отношению населения к созданию семьи, поскольку такая упрощённая процедура фактически давала возможность заключить и расторгнуть брак в один и тот же день.

Позднее был принят первый кодифицированный акт в сфере семейных правоотношений - «Кодекс законов об актах гражданского состояния, брачном, семейном и опекунском праве». В целом данный документ обобщил положения ранее принятых декретов, например, отменив многие препятствия для вступления в брак и установив 
раздельный режим имущества супругов. Также в нем закреплялись правовые последствия в случае развода, и, если заключенный брак позже признавался недействительным. Кодекс имел чрезвычайно важное значение, поскольку устранил неравенство в положении законнорожденных и внебрачных детей - отныне они имели одинаковые права. По мнению В.А. Рясенцева, Кодекс на основе новых принципов с большой полнотой регулировал брачно-семейные отношения, давая ответы и на те выдвинутые жизнью вопросы, которые в первых декретах не были решены. [3]

В 1927 году продолжился процесс регулирования отношений внутри семьи - вступил в силу Кодекс законов о браке, семье и опеке, который развивал правовые аспекты, закрепленные в предыдущем кодексе. Был урегулирован порядок расторжения брачного союза - теперь данная процедура проводилась в органах ЗАГС и суде. Изменились возрастные ограничения для вступления в брак - лицам женского пола требовалось достижение 18 лет, вместо ранее установленных 16.

Следующий этап регулирования брачно-семейных отношений начался в конце 1960-х годов. В союзных республиках СССР стали приниматься свои кодексы о браке и семье, в РСФСР же это произошло в конце 1969 года. Принятый советской властью КоБС РСФСР ввел деление общего супружеского имущества на равные доли, а также нормы, касающиеся личной собственности. На территории СССР продолжал действовать только брак, зарегистрированный в органах ЗАГС. При этом возможность проведения обряда венчания в эти годы также сохранялась. Одним из последних нормативных актов, регулировавших вопросы семьи и брака стал разработанный незадолго до распада СССР Закон № 1501-1, который дополнял ранее принятое законодательство в сфере имущественных отношений.

Итак, на основании вышеизложенного, можно сделать вывод о том, что в период до Октябрьской революции институт брака в основном регулировался имперским законодательством, основанным на церковных нормах. События 1917 года сыграли ключевую роль в преобразовании семейно-правовых отношений из церковных в светские, поскольку уже благодаря первым декретам светский брак заменил обряд венчания. Это стало отправной точкой преобразования брачного союза в ту форму, которая действует в настоящее время. В ходе эволюции семейного законодательства изменения в основном затрагивали брачный возраст и вопросы расторжения брака. Именно в процессе поэтапных изменений, вносимых в семейное законодательство, была создана ныне действующая правовая база, наиболее соответствующая потребностям современного общества, на в то же время требующая последующей доработки.

$$
* * *
$$

1. Моховая Т.А. Становление и развитие института брака в законодательстве Российской империи XIX века // Гуманитарные, социально-экономические и общественные науки. - 2014. - с.32-37.

2. Эриашвили Н. Д., Алексий П. В., Петров И. В. [и др.] Гражданское право: учебник для студентов вузов, обучающихся по специальности Юриспруденция - М., - 2012.- "Юнити-Дана" - 911 с..

3. Рудык О.И. Институт брака по российскому законодательству 1917-1922 годов // Юридическая наука и практика: Вестник Нижегородской академии МВД России. - 2010. - №2 - c.49-52

4. Кузнецов Р. Н. Семейное право: учебник - Барнаул - Барнаульский юридический ин-т МВД России- 2016. 219 c.

5. Семенова И.Ю. К вопросу об истории становления и развития институтов семьи и брака в отечественном дореволюционном и советском семейном законодательствах // Oeconomia et Jus - 2020. - №1 . - c.62-67

\section{Пиляев А.С. \\ Международно-правовой статус беженцев \\ Кубанский государственный аграрный университет имени И. Т. Трубилина \\ (Россия, Краснодар)}

doi: 10.18411/trnio-01-2022-192

Аннотация

Статья посвящена актуальным вопросам международно-правового статуса беженцев. Анализируется правовой статус беженцев, их права и обязанности на территории страны. 